\title{
MEZŐGAZDASÁGI MÜVELÉS ALATT ÁLLÓ TERÜLETEN ÁTHALADÓ KÖZÖS OSZLOPSORON LÉTESÍTETT FÖLD FELETTI HÍRKÖZLÉSI VEZETÉK SZABVÁNYI ELŐÍRÁSTÓL ELTÉRŐ BELÓGÁSÁBÓL ADÓDÓ KÁBELÁTVÁGÁSI PROBLÉMA VIZSGÁLATA
}

\author{
Varga Attila Károly \\ egyetemi docens, Miskolci Egyetem, Automatizálási és Infokommunikációs Intézet \\ 3515 Miskolc, Miskolc-Egyetemváros, e-mail: varga.attila@uni-miskolc.hu
}

\begin{abstract}
Absztrakt
A Miskolci Egyetem Automatizálási és Infokommunikációs Intézete 2020 májusában megkeresést kapott egy mezögazdasági cég által megbizott ügyvédi irodától a cég tulajdonában lévö földterület felett haladó hirközlési kábel belógásából adódó vezetékátvágás miatt inditott bírósági eljárás során a mérlegelés alapját képezö állásfoglalás elkészitése kapcsán. Tekintve, hogy a vezetékes hálózatok tervezése során a tervtartalmi követelmény és a kivitelezés müszaki tartalma eleget kell, hogy tegyen a nyomvonal jellegü épitményekkel kapcsolatos jogszabályoknak és szabványoknak, igy a vezetékátvágási ügy kapcsán készitett állásfoglalás ezen elöirásokra támaszkodva, azok részletes vizsgálatával, szükséges és nélkülözhetetlen behivatkozásokkal készült el. Jelen cikk ezen állásfoglalást mutatja be.
\end{abstract}

Kulcsszavak: vezetékes hálózat tervezése, légvezeték, hírközlés, nyomvonal jellegü épitmények, közös oszlopsorvezeték

\begin{abstract}
In May 2020, the Institute of Automation and Infocommunications of the University of Miskolc received a request from a law firm commissioned by an agricultural company in connection with the preparation of an expert opinion that can be served as a basis for consideration in the judicial proceeding initiated due to cutting a communication cable passes through a private arable land owned by the company. Given that the design content requirement and the technical content of the construction must comply with the legislation and standards for track-type structures in the design of wired networks, the expert opinion on the cutting of air cable prepared in considertion with these specifications, examining them in detail and using necessary as well as indispensable references. This article presents this expert opinion.
\end{abstract}

Keywords: design of wired networks, aerial cable, communication, trail constructions, joint-use poles

\section{Bevezetés}

Borsod-Abaúj-Zemplén megyében egy közel 17 ezer ha alapterületű szántóföldön közös oszlopsoros kivitelezésben fut keresztül egy hírközlési optikai kábel, melyet 2020 tavaszán a mezőgazdasági múvelést végző jármü elszakított miközben beleakadt abba. Ezen eseményből eredően az optikai kábel tulajdonosa, mint felperes, kártérítési igény érvényesítésére keresetet nyújtott be a területileg illetékes Járásbíróság felé. A szóban forgó jármű szabványos méretekkel rendelkező traktor és vontatmány, melynek a legmagasabb pontján mért magassága $462 \mathrm{~cm}$. 
A szántóföldön mezőgazdasági művelést végző cég, mint alperes, és az általa megbízott jogi képviselő meggyőződése, hogy az optikai kábel elhelyezése nem lehet szabályszerü akkor, amikor az a jogszerüen használt ingatlan rendeltetésszerü használatát akadályozza. Álláspontjuk szerint ugyanis az, hogy ha az optikai kábel szabályszerüen került volna elhelyezésre, úgy egy szabványos méretủ gépnek el kellett volna alatta férnie. A bírósági eljárásban rendelkezésünkre áll az optikai kábel Használatbavételi engedély kérelem dokumentáció, amivel a felperes bizonyítani kívánta, hogy az elhelyezés szabályszerü volt. Ezzel kapcsolatban az alperes részéről a jogi képviselet álláspontja, hogy amikor ezt az optikai kábelt kiépítették, akkor az ilyen jellegü tevékenység még nem volt engedélyköteles, csupán bejelentésköteles, melyre a Nemzeti Média- és Hírközlési Hatóság hívta fel a figyelmet.

Figyelemmel arra, hogy az eljáró bíróság szakkérdésnek minősítette a kérdést, így arra kötelezte az alperest, hogy bizonyítási indítványként kérjen szakértői véleményt az ügy kapcsán az alábbiakra tekintettel:

- A szakértő a felperes által becsatolt iratanyag alapján nyilatkozzon arról, miszerint a per tárgyát képező ingatlanon a felperes részéről az optikai kábel felszerelésére a jogszabályban és szabványban elöírt módon került-e sor.

- A szakértő nyilatkozni szíveskedjen arról, hogy a felperes által felszerelt optikai kábelnek a perbeli ingatlanon a földhöz viszonyítva minimum milyen távolságban kell elhelyezkednie! A földtől mért minimális távolságot milyen jogszabályra vagy szabványra alapítja a szakértő?

- A per tárgyát képező ingatlanon milyen jogszabályi és szabványi előírások alapján kell az optikai kábel kivitelezését megvalósítani?

Ezen kérdések megválaszolására tekintettel kereste meg az alperes jogi képviselete 2020 májusában a Miskolci Egyetem Automatizálási és Infokommunikációs Intézetét a hatályos jogszabályokon és szabványokon alapuló állásfoglalás elkészítése kapcsán, amelyet ezen publikáció keretein belül kívánok bemutatni.

\section{Mezőgazdasági terület megközelítése föld feletti hírközlési vezetékkel}

A térszint feletti közmü- és egyéb vezetékek közterületen való elrendezését az MSZ 7487/3-80 számú szabvány írja elő, mely alkalmazása kötelező, előirásaitól eltérést az illetékes építési hatóság engedélyezhet.

A szabvány tárgya bármely területfelhasználási kategóriába tartozó terület közterületén és külterületen a térszint felett elhelyezésre, illetve felújításra, átépítésre kerülő közcélú vezetékek, úgymint a

- villamosenergia-ellátás $120 \mathrm{kV}$ alatti vezetékei,

- távközlés,

- vízellátás,

- csapadék- és szennyvízelvezetés, (zárt csatornák)

- gázellátás,

- távhőellátás,

- helyi közlekedés vontatási energia vezetékei,

- közúti forgalomirányító és jelző berendezések vezetékei, valamint

- $\quad$ egyéb vezetékek

elhelyezési vonatkozású szabályai a föld feletti tér felhasználása szempontjából.

Az MSZ 7487/3-80 [1] számú szabvány 2.2.10. pontja elöírja, hogy:

„Mezögazdasági terület megközelitése és keresztezése estén, ha a vezeték alatt csak gyalogos közlekedés van, akkor a vezeték föld feletti magassága a legkedvezötlenebb helyzetben is legalább 3,5 m 
legyen. Ha alatta jármüvek is közlekedhetnek, akkor a jármü legmagasabb mérete felett 1,5 m maradjon szabadon, de a vezeték térszint feletti magassága legalább 5,5 m legyen."

A föld feletti hírközlési vezeték útkoronától vagy terepszint felett mért magasságára vonatkozóan irányadó:

- az MSZ 151-8:2002 és MSZ 17200-3:1999 szabvány [2][3],

- valamint az elektronikus hírközlési építmények egyéb nyomvonalas építményfajtákkal való keresztezéséről, megközelítéséről és védelméről szóló 8/2012. (I. 26.) NMHH rendelet [4].

\section{Föld feletti hírközlési vezeték közös oszlopsoron való elhelyezése}

Meglévő áramszolgáltatói infrastruktúra felhasználásával a közös oszlopsor tartószerkezetén létesítendő nyomvonalas hírközlési berendezés föld feletti magasságának meghatározása során - utak keresztezése, kapu behajtók, külterület stb. esetén - az erősáramú hálózatoknál előírt magasságot biztosítani kell. A közös oszlopsoron épült hírközlési kábel legkisebb föld feletti magasságát az MSZ 151-8:2002 számú szabvány 13.2.2. pontja az alábbiak szerint határozza meg:

„A vezetékes távközlö berendezés vezetöjét a szabadvezeték tartószerkezetén úgy kell elhelyezni, hogy bármelyik pontjának a földtöl mért legkisebb távolsága feleljen meg az MSZ 17200 szabványsorozatban elöirtaknak. Amennyiben az oszlop adottságai ennek a távolságnak a tartását nem teszik lehetővé, akkor ez a távolság a legnagyobb belógás figyelembevételével ne legyen kisebb az 5. táblázatban a terület jellege szerint elöirt távolságnál."

1. táblázat. MSZ 151-8:2002 sz. szabvány

\begin{tabular}{|c|c|c|}
\hline Sorszám & Létesítés helye & $\begin{array}{c}\text { A földtöl mért legkisebb } \\
\text { távolság [m] }\end{array}$ \\
\hline 1 & Belterületen, utak felett & 5 \\
\hline 2 & Külterületen általában, kertben, szölöben & 4,7 \\
\hline 3 & Belterületen, jármüvek be- és kijárati helyein & 4 \\
\hline 4 & Bel- és külterületen, ahol csak gyalogjárók közlekednek & 3,5 \\
\hline
\end{tabular}

\section{A Magyar Mérnöki Kamara előírásai közös oszlopsoron infrastruktúrára}

Az MSZ 151-8 sz. szabvány által a közös oszlopsor tartószerkezetén létesítendő nyomvonalas hírközlési berendezés föld feletti magasságára elöírt értékek vonatkozásában a Magyar Mérnöki Kamara honlapjáról (MMK, mmk.hu) letölthető az ELMÜ-ÉMÁSZ müszaki előírása [5]:

- 'GYR elhelyezésének müszaki elöirásai_ELMÜ ÉMÁSZ xls' kulcsszavas kereséssel (részletes keresés/tartalomban),

- továbbá az alábbi közvetlen URL-en keresztül: http://hit.mmk.hu/hirek/sziphirekmappa/gyrelmu.

(Megjegyzés: a letöltés során a fájl végéröl lemaradó .xls fájlkiterjesztés pótolandó, vagy a fájl MS Excelben a fájlkiterjesztés mellözése nélkül is megnyitható a fájlformátumra figyelmeztetö párbeszédpanel jóváhagyását követöen.) 
Az MMK oldaláról letöltött GYR (GYR: gyengeáramú, ide sorolandó az optikai kábel is, ld. táblázat alatti megjegyzés) elhelyezésének müszaki elő́rását a 2. táblázat tartalmazza.

2. táblázat. GYR elhelyezésének müszaki elöirásai (MMK)

\begin{tabular}{|c|c|}
\hline Szzempontok & ELMÜ-ÉMÁSZ \\
\hline $\begin{array}{c}\text { GYR vezeték (csatlakozó vezeték is) föld feletti magassága belterületen } \\
\text { (útcsatlakozások felett is) }\end{array}$ & $4,5 \mathrm{~m}$ \\
\hline $\begin{array}{c}\text { GYR vezeték (csatlakozó vezeték is) föld feletti magassága külterülleten } \\
\text { GYR vezeték (csatlakozó vezeték is) közút feletti magassága I. vagy II. } \\
\text { rendü utak és mellékutak, belterületi fó és mellékutak esetén }\end{array}$ & $\mathbf{4 , 7} \mathbf{m}$ \\
\hline
\end{tabular}

Part of innogy

\section{elmü hálózat}

\section{Magasságok}

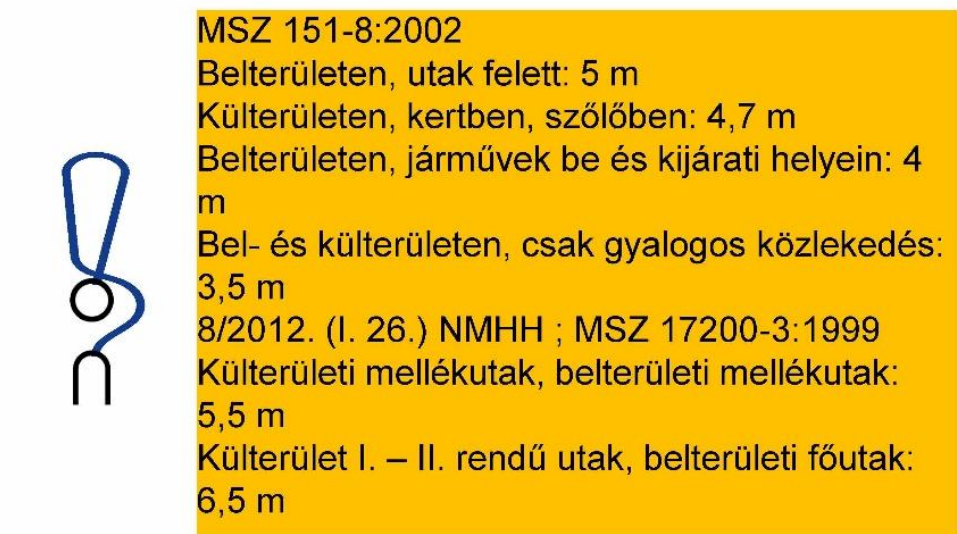

1. ábra. Közös oszlop létesités kérdései - ELMÜ-ÉMÁSZ, Märcz László [6]

A GYR az elektronikus hírközlésröl szóló 2003. évi C. törvényben az elektronikus hírközlő hálózat megfelelője): átviteli rendszerek és - ahol ez értelmezhető - a hálózatban jelek irányítására szolgáló berendezések, továbbá más erőforrások - beleértve a nem aktív hálózati elemeket is -, amelyek jelek továbbítását teszik lehetővé meghatározott végpontok között vezetéken, rádiós, optikai vagy egyéb elektromágneses úton, beleértve a múholdas hálózatokat, a helyhez kötött és a mobil földfelszíni hálózatokat, az energiaellátó kábelrendszereket, olyan mértékben, amennyiben azt a jelek továbbítására használják, a müsorszórásra használt hálózatokat és a kábeltelevíziós hálózatokat, tekintet nélkül a továbbított információ fajtájára. 
A közös oszlopsor tartószerkezetén létesítendő nyomvonalas hírközlési vezeték föld feletti magasságára előírt értékeket Märcz László müszaki szakértő (ELMÜ-ÉMÁSZ) Közös oszlop létesités kérdései c. dokumentumának 9. oldala foglalja össze (ld. 1. ábra).

\section{5. Összefoglalás}

Az előbbiekben taglaltak alapján tehát a föld feletti, közös oszlopsoros hírközlési vezeték elhelyezésénél az útkoronától vagy terepszint felett mért magasság külterületen az ELMÜ-ÉMÁSZ müszaki előírásai alapján 4,7 m. Ebből következően tehát 4,7 m magasság alatti jármü a föld feletti hírközlési vezeték alatt, annak elszakítása nélkül biztonságosan át tud haladni.

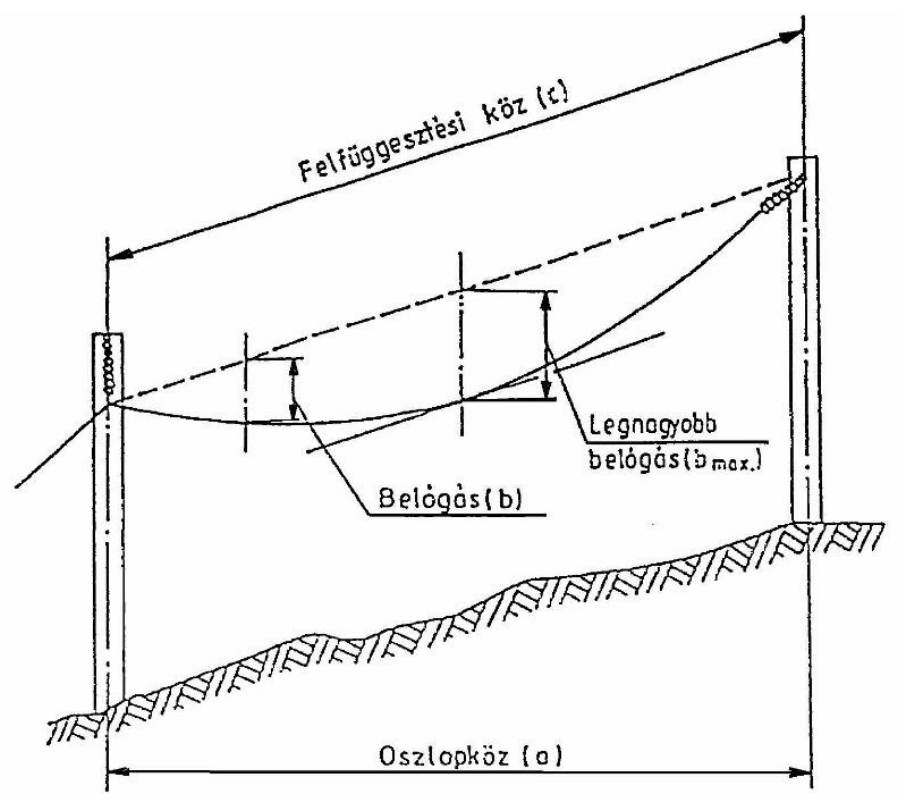

2. ábra. Vezetékbelógás értelmezése - MSZ 151-1:2000 szabvány [7]

Megállapítható tehát, hogy a közös oszlopsoros hírközlési vezetéket az alatta áthaladó legmagasabb ponton mért 4,62 m magasságú jármü csakis abban az esetben szakíthatta el, amennyiben az egy oszlopközben belógó vezeték felerősítési pontjait összekötő húrral párhuzamos érintő érintkezési pontjának a húrtól mért legnagyobb függőleges távolsága (legnagyobb belógás definíciója, MSZ 151-1:2000 szabvány, ld. 2. ábra) olyan mértékü volt, mely következtében az ELMÜ-ÉMÁSZ müszaki elöírásában a külterület vonatkozásában megadott terepszint és a föld feletti hírközlési vezeték közötti 4,7 m magasság nem volt biztosítva.

\section{Köszönetnyilvánítás}

A cikkben ismertetett kutatómunka az EFOP-3.6.1-16-2016-00011 jelü Fiatalodó és Megújuló Egyetem - Innovativ Tudásváros - a Miskolci Egyetem intelligens szakosodást szolgáló intézményi fejlesztése projekt részeként - a Széchenyi 2020 keretében - az Európai Unió támogatásával, az Európai Szociális Alap társfinanszírozásával valósul meg. 


\section{Irodalom}

[1] MSZ 7487/3-80 szabvány, Magyar Szabványügyi Testület: Közmü- és egyéb vezetékek elrendezése közterületen. Elhelyezés a térszint felett, www.mszt.hu (dokumentumazonosító: 008971).

[2] MSZ 151-8:2002 szabvány, Magyar Szabványügyi Testület: Erősáramú szabadvezetékek. A legfeljebb 1 kV névleges feszültségü szabadvezetékek létesitési elöirásai, www.mszt.hu (dokumentumazonosító: 121584).

[3] MSZ 17200-3:1999 szabvány, Magyar Szabványügyi Testület: Nyomvonalas távközlö létesitmény megközelitési és keresztezési elöirásai. 3. rész: Utak, hidak, felüljárók, aluljárók, alagutak, www.mszt.hu (dokumentumazonosító: 071574).

[4] Az elektronikus hírközlési épitmények egyéb nyomvonalas épitményfajtákkal való keresztezéséröl, megközelitéséről és védelméröl szóló 8/2012. (I. 26.) NMHH rendelet, net.jogtar.hu.

[5] Märcz, L. (müszaki szakértő, ELMÜ-ÉMÁSZ): Közös oszlop létesités kérdései, 2017, http://mknonprofitkft.hu/oktafile.php?file_id=1688\&p=1, 2017.

[6] MSZ 151-1:2000 szabvány, Magyar Szabványügyi Testület: Erösáramú szabadvezetékek. $1 \mathrm{kV}$ nál nagyobb névleges feszültségü szabadvezetékek létesitési elöirásai, www.mszt.hu (dokumentumazonosító: 073524). 